Spring 1994

\title{
The Socialist Polis: Antiquity and Socialism in Marx's Thought
}

\author{
Claudio Katz \\ Loyola University Chicago, ckatz@luc.edu
}

Follow this and additional works at: https://ecommons.luc.edu/politicalscience_facpubs

Part of the Political Science Commons

\section{Recommended Citation}

Katz, C. "The Socialist Polis: Antiquity and Socialism in Marx's Thought." Review of Politics 56(2), 1994.

This Article is brought to you for free and open access by the Faculty Publications and Other Works by Department at Loyola eCommons. It has been accepted for inclusion in Political Science: Faculty Publications and Other Works by an authorized administrator of Loyola eCommons. For more information, please contact ecommons@luc.edu.

\section{(c) (i) $\Theta \Theta$}

This work is licensed under a Creative Commons Attribution-Noncommercial-No Derivative Works 3.0 License. (c) University of Notre Dame, 1994. 


\section{The Socialist Polis: Antiquity and Socialism in Marx's Thought}

\section{Claudio Katz}

The central question guiding this essay is: what does Marx's socialism owe to classical antiquity? Underlying this question is the thesis that Marx's studies of classical Greece supply the angle of vision necessary to bring to light the hallmark of his conception of the socialist polity. The argument challenges a widespread interpretation of the connection between antiquity and socialism in Marx's work-that his socialist vision takes its bearings from the Aristotelian understanding of the relationship between necessity and leisure. In Marx's view, the fundamental legacy of antiquity was the notion of freedom as masterlessness. The roots of this legacy are in the political experience of the democratic polis, not in Aristotle's reflections on the ideal household. The core of Marx's project, then, is not to open a realm of freedom beyond necessity, but rather to create spaces for democratic action within the realm of necessity itself, to ensure that work is free and compatible with leisured activities.

The sudden collapse of communism has created an opportunity for a renewed examination of Marx's utopian imagination. Freed from the passions of the cold war, scholars have begun to investigate the rich complexity of traditions from which Marx drew his critique of capitalist society. Their studies have deepened our understanding of the profound influence of classical antiquity on his thought. Marx repeatedly acknowledged his fascination with the world of the ancients, and there is general agreement that his socialist vision is fundamentally indebted to the Greek experience.

Underlying a widespread view of the nexus between antiquity and socialism in Marx's thought, however, is an account of the polis Marx did not share. William Booth, to take its most prominent exponent, maintains that Marx's angle of vision takes its bearings from Aristotle's reflections on the household economy. ${ }^{1}$

1. William James Booth, Households, On the Moral Architecture of the Economy (Ithaca, NY: Cornell University Press, 1993); Booth, "The New Household Economy," American Political Science Review 85 (March 1991): 59-75; Booth, "Economies of Time, On the Idea of Time in Marx's Political Economy," Political Theory 
For Aristotle, the economy was a sphere of constraint, dominated by the necessities of life. Household management (oikonomia) was charged with securing the possessions required for the satisfaction of daily recurring needs; the purpose of acquisition, however, was to release unbound time for the pursuit of higher, nonmaterial ends. Leisure (scholē), abstention from all necessary work, made possible activities directed toward the development of a properly human excellence. The best community was characterized by bonds of friendship grounded in shared perceptions of the morally good life.

In Booth's view, "Marx's attention" was drawn above all by "the connection between the economy, the time it made available, and freedom, a relationship set out with greatest clarity in The Politics." ${ }^{2}$ The core of Marx's socialist project was to restore something like the Greek household economy, to create a "vast oikos" where the technological accomplishments of capitalism are harnessed in the service of conquering economic necessity. ${ }^{3}$ This is an essentially apolitical conception of socialism: politics gives way to housekeeping, now centralized and written large, for the purpose of maximizing leisure as the basis of freedom-from want, from work, and from political activity. ${ }^{4}$ Material progress

19 (February 1991): 2-27. Another major line of investigation explores the Aristotelian lineages of Marx's theory of justice and the good life. See, e.g., Richard W. Miller, "Marx and Aristotle: A Kind of Consequentialism," in Canadian Journal of Philosophy, supp. vol. 7 (1981): 323-352; Alan Gilbert, "Marx's Moral Realism: Eudaimonism and Moral Progress," in After Marx, ed. Terence Ball and James Farr (Cambridge: Cambridge University Press, 1984); Jon Elster, "Self-Realization in Work and Politics: The Marxist Conception of the Good Life," Social Philosophy and Policy 3 (Spring 1986): 97-126; Michael DeGolyer, "The Greek Accent of the Marxian Matrix," in Marx and Aristotle, ed. George E. McCarthy (Savage, MD: Rowman and Littlefield, 1992), pp. 107-153. Although clearly related to the theme of this article, this literature does not address its central concerns, the conception of freedom and necessity in Marx and Aristotle.

2. Booth, Households, p. 253.

3. Ibid., pp. 249-96; see also Booth, "The New Household Economy," pp. 60, 69-72.

4. Booth, Households, pp. 251-62, 270. For similar conceptions of Marx's socialism, see Hannah Arendt, Between Past and Future (New York: The Viking Press, 1956), pp. 17-25; Agnes Heller, The Theory of Need in Marx (London: Allison and Busby, 1976), pp. 96-130; G. A. Cohen, Karl Marx's Theory of History, A Defence (Princeton: Princeton University Press, 1978), pp. 302-325; Adam Przeworski, "Material Interests, Class Compromise, and the Transition to Socialism," in 
enables society to contain the economy within "the smallest possible compass"; beyond it lies a realm of freedom "in which persons choose to spend their days together, doing whatever it is they love best in life." ${ }^{15}$ Free time in the socialist community is vacant and individualist: men and women "do "what they love best of everything' in each other's company, if they so choose; they have a 'free association' because their bonds are ... adopted by them."6

This interpretation does not adequately reflect Marx's own understanding of his debt to antiquity. Reading Marx from the perspective of Aristotle's distinction between work and leisure yields an extremely selective view of his conception of the socialist polity. Notably absent from accounts of Marx's relationship to the ancients is a discussion of his historical analysis of the polis, most clearly set out in the Grundrisse. ${ }^{7}$ Marx's studies of classical antiquity, relying mainly on Greek and contemporary sources, provided a theory of the polis with striking parallels to that of Aristotle. ${ }^{8}$ The similarity between them, however, lies in their political sociology. ${ }^{9}$ Marx rejected Aristotle's normative economics and his ideal of the polis and its virtues. His socialist project draws upon and adapts the unique accomplishments of the Athenian demos in ways that sharply contradict Aristotle's judgements of Athenian political practice.

Analytical Marxism, ed. John Roemer (Cambridge: Cambridge University Press, 1986), pp. 181-88.

5. Booth, Households, pp. 256, 255.

6. Ibid., p. 256.

7. For an exception, see Patricia Springborg, "Politics, Primordialism, and Orientalism: Marx, Aristotle, and the Myth of the Gemeinschaft," American Political Science Review 80 (March 1986): 185-211.

8. For discussions of Marx as a classical scholar, indicating his familiarity with Greek sources, especially the works of Aristotle, see G. E. M. de Ste. Croix, The Class Struggle in the Ancient Greek World, from the Archaic Age to the Arab Conquests (Ithaca, NY: Cornell University Press, 1981), pp. 23-25; George E. McCarthy, "Visions and Vertigo: Viewing Modernity from the Acropolis," in McCarthy, Marx and Aristotle, pp. 1-3; Michael DeGolyer, "The Greek Accent of the Marxian Matrix," pp. 107-119.

9. See Josiah Ober, "Aristotle's Political Sociology: Class, Status, and Order in the Politics," in Essays on the Foundations of Aristotelian Political Science, ed. Carnes Lord and David K. O'Connor (Berkeley: University of California Press, 1991). 
In this article, I argue that Marx's socialist vision is derived from the historical experience of the democratic polis. What he learned from Aristotle is an understanding of its potentialities as a distinct form of rule. Marx's ideal of the free society both returns to and transforms the Aristotelian idea that the human being is a political animal (zōon politikon), where political refers to the civic community and the kind of rule appropriate to it. Marx's distinctive contribution to this idea is the argument that civic community and class constitute alternative and contradictory ways of organizing the economy. The concept of class served to focus Marx's thinking about the process of ruling, involving both a ruler and a subject, within the realm of necessity. Class is the nucleus of Marx's normative economics; its abolition, the creation of a classless society, is the objective of the socialist project. The democratic polis, best depicted in Aristotle's texts, played a crucial role in the development of this understanding: Marx discovered in it the political form for abolishing and superseding classes.

The core of Marx's socialist vision, then, is not to create a realm of freedom beyond the economy. To be sure, Marx stressed that material progress was an essential prerequisite of human emancipation. But the full significance of his conception of socialism is obscured by viewing it only in this light, in which freedom is seen as a function of technological innovation and politics simply "withers away." Marx's main concern is to open spaces for democratic action within the realm of economic necessity, to ensure that work itself is free, designed by workers themselves. Socialism envisages a citizenry engaged in resolving, in free deliberation within civic communities, the dialectic between what they are capable of technically and what they want in practice. Democratic politics supplants class as the principal means by which what is necessary is decided and distributed.

This article is divided into two main parts. The first section argues that, for Marx, the hallmark of the democratic polis is the tension between civic community and class. The second section maintains that the experience of ancient democracy informed Marx's understanding of socialist emancipation. Its focus will be a study of Marx's writings on the Paris Commune of 1871, the single most significant influence on his political thought during the last decade of his life. What impressed him about the Commune was precisely what impressed him about the polis: it pro- 
vided the political form to free human beings from class rule. A concluding section explores the relationship between Marx's theory of socialist politics and the theory of participatory democracy.

\section{Marx on the Ancient Economy and Polity}

What did Marx learn about economics from the ancient Greeks? I will argue that Aristotle's theory of the ideal household obscures Marx's own view of the antique economy and its most significant legacy to the modern world. Aristotle's distinction between economic life and the life of virtue corresponds to a distinction, common among the ancient aristocracy, between the domains of necessity and freedom. ${ }^{10}$ Economic life comprised those activities imposed on human beings by the unrelenting demand of satisfying daily needs. Living under the constraint of economic necessity was ignoble, something the human animal shared with other animals. A truly human existence presupposed leisure, an indispensable though not sufficient condition of a noble and good life. ${ }^{11}$

The ideal household enjoyed sufficient property to relieve the head of the household from necessary sorts of work, permitting pursuits proper to a gentleman. Property secured the household's command over the labor of others, especially slaves. Rule over slaves was justified as the only means to master necessity and to become free. ${ }^{12}$ In excluding material work from the realm of freedom, however, Aristotle extended the meaning of living under constraint beyond slaves to anyone who was dependent on economic activity. The opposite of leisure is work per se, whether under the compulsion of nature or convention. ${ }^{13}$ Slaves and free poor are both under the inescapable necessity of working for a

10. Moses I. Finley, The Ancient Economy (Berkeley: University of California Press, 1973), pp. 40-41; Ste. Croix, Class Struggle in the Ancient Greek World, pp. 114-17, 182-85.

11. Aristotle, Politics, trans. Carnes Lord (Chicago: University of Chicago Press, 1984), 1326b30-32, 1329a1-2, 1333a33-36 (hereafter cited as Pol.).

12. Ibid., 1253b30-1254a10.

13. Ibid., 1269a34-36, 1277a35-1277b7, 1291b24-26, 1292b24-30. See also Booth, Households, pp. 44, 70-73; Finley, The Ancient Economy, p. 41. 
living. ${ }^{14}$ Although they formed the core of Athenian democracy, Aristotle excludes working farmers and craftsmen from the best forms of life and citizenship. ${ }^{15}$

In his own reflections on the human relationship with nature, Marx fundamentally redeploys the conceptual framework of Aristotle's normative economics. Like Aristotle, Marx maintains that work itself "is the everlasting Nature-imposed condition of human existence, ... . independent of every social phase of that existence, or rather, is common to every such phase." ${ }^{16}$ Nature comprises a realm of constraint in all forms of society, including a socialist one. Some kind of concrete labor, however determined, is required to reproduce human life. In Marx's view, however, this transhistorical realm of necessity is historically modified in different types of society. ${ }^{17}$ What people are constrained to do for a living in any given social formation constitutes a historically determined realm of necessity.

For Marx, two different definitions of freedom correspond to these realms of necessity-leisure and masterlessness. Leisure refers to freedom from any kind of concrete labor, from transhistorical necessity. Unlike Aristotle, however, Marx argues that the crucial arena of freedom lies within the realm of historically determined economic necessity. Its content is masterlessness, the freedom of individuals (singly or collectively) to direct their own economic activities. Especially "in its historical forms of slave labor, serf labor and wage labor, work is always repulsive and always appears as externally imposed, forced labor, and as against that not-work as 'liberty and happiness.'"18 The opposite of freedom here is not necessary work per se, but necessary work commanded by and for the sake of someone else. The central distinction is between independent and dependent work. Pro-

14. Aristotle Pol. 1278a7-13.

15. Ibid., 1329a1-2, 1330a26-27.

16. Karl Marx, Capital, trans. Samuel Moore and Edward Aveling, ed. Frederick Engels, 3 vols. (Moscow: Progress Publishers, n.d.-1971), 1: 179; see also Capital 3: 820.

17. Cf. Moishe Postone, Time, Labor, and Social Domination (Cambridge: Cambridge University Press, 1993), pp. 373-84.

18. Karl Marx, Grundrisse, in Karl Marx and Frederick Engels, Collected Works, 50 vols. projected (Moscow: Progress Publishers, 1975-), 28: 530 (hereafter cited as $\mathrm{CW}$ ). 
ductive activity, Marx argues, may be a "manifestation of freedom" whenever its "external aims are ... posited as aims which only the individual himself posits, ... and thus real freedom, whose action is precisely work." 19

Marx's distinction between independent and dependent work corresponds to a definition of the economic sharply at odds with Aristotle's. For Marx, the economy comprises in the first instance class relationships, not the production of human sustenance..$^{20}$ The concept of class gave Marx a critical purchase on the process of ruling within a society's historically determined realm of necessity. Classes form at the intersection of property and sovereignty. Property in the prevailing means of production invests its owners with sovereignty over the material "destinations and risks" of other people. ${ }^{21}$ Members of the subordinate class are subject to the authority of their superiors, constrained to produce for them. Exploitation refers to the process whereby the direct producers are compelled to transfer an economic surplus beyond what they must produce to satisfy their own needs to maintain the members of the dominant class.

Commentators have questioned the applicability of Marx's theory of class to precapitalist economies. ${ }^{22}$ In their view, class is a purely economic phenomenon, arising from the nexus of activities of market participants. The premise that class is an economic category in this sense makes nonsense of any attempt to apply it to precapitalist societies. But Marx took leave of this narrow definition in favor of an understanding of the economy as a society's relations of power over persons and productive resources. ${ }^{23}$ Only in a capitalist society does the economy in its

19. Ibid.

20. Marx, Capital 3: 791-92.

21. Michael Walzer, Spheres of Justice (New York: Basic Books, 1983), p. 291.

22. See, for example, Booth, "The New Household Economy," pp. 59, 64; Finley, The Ancient Economy, pp. 48-50. Finley returns to the language of "class" in his later studies of the ancient economy, although he stresses that this "does not imply a change of view." The poor of the ancient world, he argues, "were all the free men who labored for their livelihood... . They were distinguished from the 'rich,' who were able to live comfortably on the labor of others" (Moses I. Finley, Politics in the Ancient World [Cambridge: Cambridge University Press, 1983], p. 10 and n. 29). I fail to see how this usage of the term differs in any fundamental way from Marx's own.

23. Marx, Capital 1: 209; 3: 791-92. 
broad sense take the form of an economy in its narrow sense. The bourgeois property order sheds its political skin: control over labor is mediated by free exchange relations.

In contrast, precapitalist property is directly vested with political authority. The subordinate position of premodern producers was achieved through various forms of juridical dependence supported by manifest force-slavery, debt-bondage, serfdom, corvee labor, and so on. In Marx's words, surplus was extracted "by other than economic pressure." 24 Tax and rent comprised the main forms of appropriation. The specific way in which surplus is levied from the subject producers, for example, by means of the centralized state or the institution of lordship, serves to distinguish different types of precapitalist economic formations. ${ }^{25}$ Precapitalist societies are characterized by the embedded quality of the economic domain in relation to society. ${ }^{26}$ What is embedded, however, is not primarily the market but rather the network of ownership relations through which "unpaid surplus labor is pumped out of direct producers." 27

The peasant community, Marx argues, constituted the economic foundation of precapitalist social formations. ${ }^{28}$ Its basic component was the individual holding of the peasant family. The typical holding formed a natural economic cell in the sense that the material conditions of its continued existence were directly replaced out of the household economy itself. Peasant holdings were not, however, economically autonomous units. They were embedded within villages that tightly regulated the production process and the social and moral life of the whole community. Nor were industry and agriculture specialized spheres of production, separated in town and country; they were interwoven into rural life. Craftsmen were integral members of peasant villages, performing essential ancillary functions for agricultural production. The governing aim of these communities was self-suffi-

24. Ibid., 3: 791.

25. Marx, Capital 3: 790-91; 1: 226-29; Marx, Grundrisse, CW 28: 400-402.

26. Karl Polanyi, "Aristotle Discovers the Economy," in Primitive, Archaic and Modern Economies, Essays of Karl Polanyi, ed. George Dalton (Garden City, NY: Anchor Books, 1968), p. 81.

27. Marx, Capital 3: 791.

28. Marx, Grundrisse, CW 28: 399-401, 408-410, 421-22. 
ciency, "the reproduction of their individual members as proprietors, i.e. in the same objective mode of existence, which also constitutes the relationship of the members to each other, and therefore constitutes the community itself." ${ }^{29}$

What, then, is Marx's understanding of the distinguishing feature of the Greek polis? Marx's attention is drawn by the extraordinary degree of economic independence won by ordinary producers:

Free self-managing peasant proprietorship of land parcels as the prevailing, normal form [of ownership] constitutes ... the economic foundation of society during the best periods of classical antiquity. ${ }^{30}$

Smallholders working on their own account, without much property of their own, formed the vast majority of the working population and produced the bulk of its goods. ${ }^{31}$ They may have owned slaves, but certainly not in numbers sufficient to release them from the need to work for a living. ${ }^{32}$ What distinguished the Attic peasants from other premodern peasant communities is not

\section{Ibid., p. 417.}

30. Marx, Capital 3: 806. There is a tension in Marx's work between his ascription of the economic base of antiquity to, on the one hand, slave labor and, on the other, independent peasant production. His most extended commentary on the economy of the classical polis-in the section of the Grundrisse on precapitalist formations-assigns primacy to the free peasantry. Moreover, Marx repeatedly maintains that "peasant agriculture on a small scale, and the carrying on of independent handicrafts ... form the economic foundation of the classical communities at their best" (Marx, Capital 1:316n. 3; also 345 n. 1). I contend that, for Marx, the most important legacy of classical Greece is the relationship between citizenship and the abolition of class rule. Interpretations of Marx which focus solely on the equation between classical culture and slavery miss this underlying theme in his work. Although Wood maintains that Marx described ancient Greece as a slave mode of production, Marx's own historical writings on the polis anticipate her thesis that "the distinctive characteristic of Athenian democracy was ... the extent to which production rested on free, independent labor to the exclusion of labor in varying forms and degrees of juridical dependence or political subjection" (Ellen Meiksins Wood, Peasant-Citizen and Slave [London: Verso, 1988], p. 82). This is also Finley's view of the remarkable novelty of ancient democracy (Moses I. Finley, Ancient Slavery and Modern Ideology [New York: Viking, 1980], pp. 89-90).

31. Marx, Grundrisse, CW 28: 402-404. See also Ste. Croix, Class Struggle in the Ancient Greek World, pp. 114-15.

32. See Aristotle Pol. 1252b10-15, 1323a5. 
the extent to which they escaped the harsh compulsion to toil, but the degree to which they liberated themselves from the constraint of toiling for the sake of others. Small producers gained free ownership of their lands and secured their personal freedom, sharply limiting demands upon their labor and its product. Masterlessness, the ideal of peasants since time immemorial, came to fruition in the Athenian peasant village.

This accomplishment-the virtual abolition of premodern relationships of class rule-is the special product of Greek democracy. The democratic regime established an integral connection between political self-rule and economic masterlessness:

The community as a State is on the one hand the relationship of these free and equal private proprietors to each other, their combination against the outside world-and it is at the same time their safeguard. Communal life is here based as much on the fact that its members are working landed proprietors, smallholding peasants, as the peasants' independence is based on their mutual relation as members of the community, on safeguarding the ager publicus for the communal needs and the communal glory.... The precondition for the survival of this community is the maintenance of equality among its free self-sustaining peasants, and their own labor as the condition for the continued existence of their property. ${ }^{33}$

Marx's historical study of the democratic polis bears a remarkable resemblance to that of Aristotle. Aristotle maintains that the critical factor in the development of Athenian democracy was the independence of its citizens. Solon's reforms, he argues, "put an end to the slavery of the people, and established the traditional democracy." ${ }^{34}$ Slavery here refers not to chattel slavery but rather to debt-bondage through which the majority of cultivators were reduced to conditions of personal dependence, owing tribute and service to their aristocratic counterparts. Solon forged a close link between economic emancipation and civic freedom; he abolished all forms of debt-bondage (in the famous seisachtheia or shaking-off of burdens) and secured this through limited democratic reforms. This link forms one of the deep themes

33. Marx, Grundrisse, CW 28: 403.

34. Aristotle Pol. 1273b35-40. See also Aristotle, The Athenian Constitution, trans. P. J. Rhodes (Harmondsworth: Penguin Books, 1984), chaps. 5-12. 
of Athenian history. ${ }^{35}$ Although critical of what he calls the "extreme form" of democracy, Aristotle makes it clear that the smallholders defended the democratic regime precisely because it preserved their personal liberty. ${ }^{36}$ This sort of regime, he writes, is based on their ideal of "not being ruled by anyone, or failing this, [to rule and be ruled] in turn."137

Marx adopts Aristotle's view that the democratic polis had a distinctly economic base: its radical innovation, novel in the ancient world and rarely repeated since, is the position of the small producers as full members of the political community, as citizens. Like Aristotle, he argues that the polis is a uniquely civic partnership, differing in kind from both the loose tribal organization of Germanic peoples and the centralized state of the Asian empires. "Among the Germanic peoples," Marx writes, "the community does not ... exist as a State, ... as among the ancients, because it does not exist as a city." Here, "the tiller of the soil is not a citizen." ${ }^{39}$ In the Asiatic empires peasant communities are subjects of the state. Their "all-embracing unity ... [is] realized in the despot as the father of the many communities" that support his rule. ${ }^{40}$

In contrast, Marx argues, the Attic peasant finds himself in "the dual relationship which makes him both a citizen with equal status, belonging to the community, and a proprietor." ${ }^{.41}$ Drawing on the work of Niebuhr, Marx notes that one of the hallmarks of Athenian history, most commonly associated with the reforms of Cleisthenes, is the displacement of kinship and tribal ties by new civic bonds predicated on the political incorporation of the peasant community (or deme). ${ }^{42}$ The urban center of the polis provided

35. See Orlando Patterson, Freedom (New York: Basic Books, 1991), pp. 66-77; Wood, Peasant-Citizen and Slave, pp. 93-107; Finley, Politics in the Ancient World, pp. 106-110, 139-40; Ste. Croix, Class Struggle in the Ancient Greek World, pp. 96-97, $298,317$.

36. Aristotle Pol. 1317a40-1317b17.

37. Ibid., 17b14-16; see also Thucydides, The Peloponnesian War, trans. Rex Warner (Harmondsworth: Penguin Books, 1954), 2. 37, 41.

38. Compare Marx, Grundrisse, CW 28: 400-402, 406-408 with Aristotle Pol. 1327b20-30. See also Marx, Capital 1: 86 n., 309 n. 3.

39. Marx, Grundrisse, CW 28: 407, 408.

40. Ibid., pp. 400-401.

41. Ibid., p. 418.

42. Ibid., pp. 405-406. 
a permanent space for political action; politics strictly defined referred to the activity of citizens gathered together to raise and challenge rival claims to rule. This is not to say that property differentials were abolished; although the democratic regime precluded sharp material disparities among citizens, land was not generally redistributed. Conflict between rich and poor remained a basic feature of the democratic polis. Civic equality undermined the political attributes of property, the relations of juridical dependence and political subjection whereby the rich traditionally commanded the services of the poor. The polis thus pioneered a new form of rule, between free and equal individuals sharing in deliberation and office, markedly different from rule in the household, whether the centralized household of the Oriental despot or the private household of the individual master.

Working from Aristotle's definition of humans as political animals, Marx argues that individuals realize their full potential only in and through community with others. "Man is a $z \bar{o} o n$ politikon in the most literal sense: he is not only a gregarious animal, but an animal that can individuate itself only within society. ${ }^{\prime 43}$ In the History of Animals, Aristotle suggests that human beings are unique among gregarious animals in that they use their communities for both communal and individual purposes. ${ }^{44}$ For Marx, the political relationship is a uniquely historical product: "Man becomes individualized only through the process of history. Originally he is a species being, a tribal being, a herd animal-though by no means a zōon politikon in the political sense." ${ }^{45}$ Among precapitalist formations, he maintains, the ancient civic association achieved the appropriate balance between individual and collective self-determination.

Marx's historical analysis of antiquity belies some of the most widely held views about the relationship between the Athenian

43. Ibid., p. 18 (translation slightly amended).

44. Aristotle, Historia Animalum, trans. A. L. Peck (Cambridge: Harvard University Press, 1965), 488a.

45. Marx, Grundrisse, CW 28: 420. In this and the previous quote zōon politikon appears in Greek, suggesting that Marx wished to adhere to the original meaning of the term. For an account of Marx's usage of this term, see Nancy L. Schwartz, "Distinction Between Public and Private Life, Marx on the Zōon Politikon," Political Theory 7 (May 1979), pp. 253-56. 
polity and economy. He takes leave of the notion that the development of Athenian democracy was predicated on shifting the burden of necessary work to dependent labor, principally slaves, thereby providing citizens with the requisite leisure to engage in political activity. ${ }^{46}$ Marx contends that democratic politics enabled ordinary producers to escape exploitation. Indeed, recent historical studies suggest that ancient slavery was the product rather than the precondition of democracy, helping to reconcile the propertied classes to the new regime by supplying them with an alternative source of dependent labor once the peasants ruled out existing forms of surplus appropriation. ${ }^{47}$ Moreover, it is likely that peasants, already the most underemployed class in premodern societies, increased the time available for politics by their success in restricting the time traditionally spent working for others..$^{48}$

For Marx, then, the most revolutionary feature of the polis, in particular of democratic Athens, was its unique nexus between civic community and class. His main interest in political rule, unlike Aristotle's, is not in its potential for the exercise of moral virtue. Democratic political practice ensured economic freedom, transforming the historically determined realm of necessity. Marx defined the polis in terms of the class relationship between citizens, not the relationship between slave and free members of the household. Leisured landowners and subsistence cultivators constituted the main class axis within the citizen body. The creation of a civic community incorporating both classes made the very existence of class rule the focus of political argument and conflict. Athens was an acutely political economy. Neither market nor household relations, however, were the most pervasive sources of strife. Athenian politics were mainly about class. The wealthy sought to restore the political entailments of their property while the poor struggled to suppress or abrogate them entirely. Their conflicts turned on two very different notions of freedom and the relationship between freedom and necessity. Both large and small

46. See, for example, Booth, Households, pp. 60, 63, 96 .

47. Finley, Ancient Slavery and Modern Ideology, pp. 67-92; Patterson, Freedom, pp. 64-81. See Josiah Ober, Mass and Elite in Democratic Athens: Rhetoric, Ideology, and the Power of the People (Princeton: Princeton University Press, 1989), pp. 20-35.

48. See Wood, Peasant-Citizen and Slave, p. 109. 
proprietors defined their freedom as the antithesis of slavery. ${ }^{49}$ But smallholders conceived the contrast as one between working on their own account and working for the sake of others, whereas their aristocratic compatriots conceived it as one between necessary work and leisure..$^{50}$ Aristotle defined the gentleman as a "free man" in the sense that he is fully free from the need to gain a livelihood; he neither lives "in dependence on others" nor practices any "servile" or "vulgar" occupation. ${ }^{51}$ For the peasants, freedom meant independence, working on their own plots unconstrained by obligations of debt or service to others. ${ }^{52}$

\section{The Socialist Polis}

Booth maintains that Marx returned to the Greeks to capture the meaning of a dream humankind long possessed and could now be realized in practice-the idea of a new oikos community. ${ }^{53}$ Marx's own account of this dream is rather different:

49. Patterson, Freedom, pp. xiii-xvi, chaps. 3-8.

50. Contemporary scholarship has challenged the view that smallholders defined the freedom to which they aspired in aristocratic terms (contrast Booth, Households, p. 45 with Wood, Peasant-Citizen and Slave, pp. 126-137). This is not to say that small property owners rejected slave labor, if they could afford it, as a supplement to their own; what they fought for and won, however, was economic independence, "their personal freedom and their tenure on the land" (Finley, Ancient Slavery and Modern Ideology, p. 89). In a similar vein, current research has questioned the notion that the ancient world was uniformly contemptuous of manual work. Rather, it is more plausible to suggest that pride in one's work was prevalent in a society in which peasants and craftsmen were citizens. Protagoras's account of political life in democratic Athens must have reflected a shared conviction among small farmers and artisans about their material and moral contributions to Greek civilization (Plato, Protagoras, trans. Martin Ostwald [Indianapolis: Bobbs-Merrill, 1956], 320c-328d). Evidence that craftsmen signed their work and referred to their skills with pride in their dedications and epitaphs suggests that they did not share the contempt of their work that prevailed among the ancient aristocracy. See Ste. Croix, Class Struggle in the Ancient Greek World, pp. 274-75. Marx himself locates the genesis of the notion of the good life as one of active self-realization through work in the experience of the independent peasant and artisan (Capital, 1: 713, 344-46).

51. Aristotle, The "Art" of Rhetoric, trans. John Henry Freese (London: William Heinemann, 1967), 1367a28-32.

52. Thucydides Peloponnesian War 2. 37, 41; Wood, Peasant-Citizen and Slave, pp. 126-37.

53. Booth, Households, pp. 73-74, 295. 
The self-confidence of the human being, freedom, has first of all to be aroused again in the hearts of these people. Only this feeling, which vanished from the world with the Greeks, and under Christianity disappeared into the blue mist of the heavens, can again transform society into a community of human beings united for their highest aims, into a democratic state. ${ }^{54}$

The view from the democratic assembly informed Marx's earliest conception of the possibilities for human emancipation. The special accomplishment of the bourgeois revolutions, he argued, is the recreation of classical principles of civic association. ${ }^{55}$ The revolution against feudal rule founded a permanent space for democratic action. ${ }^{56}$ Universal suffrage ensures access to a public forum where "every member of the state participates in deliberating and deciding on the general affairs of the state." ${ }^{57}$ Just as important, equal membership in the political community is closely tied to self-respect and mutual recognition. ${ }^{58}$ Drawing on Aristotle, Marx equates the life of a person excluded from public deliberation and decision with the life of "an animal." 59

The achievements of modern democratic revolutions, however, are sharply limited. Contemporary democratic regimes are bourgeois democracies. ${ }^{60}$ This is not to say that the state is merely an instrument of the propertied classes, nor that modern representative institutions constitute a corrupt departure from a purer, more participatory form of democracy. Marx displays no

54. Karl Marx, "Letters from the Deutsch-Französische Jahrbücher," CW 3: 137. The "dream long possessed" phrase is from a letter to Ruge of September 1843; I am quoting from a letter to Ruge of May 1843, where Marx also indicates that restoring the human world entails restoring Aristotle's idea that the human being is a $z \bar{o}$ on politikon. Both letters are part of a collection in which Marx and Ruge drew up their plans for the Deutsch-Französische Jahrbücher, and later published in that journal.

55. Karl Marx, Contribution to the Critique of Hegel's Philosophy of Law, CW 3: 29-33, 115-21.

56. Karl Marx, On the Jewish Question, CW 3: 160-61, 166.

57. Marx, Contribution to the Critique of Hegel's Philosophy of Law, CW 3: 117.

58. Marx, On the Jewish Question, CW 3: 154-55. 117.

59. Marx, Contribution to the Critique of Hegel's Philosophy of Law, CW 3: 51,

60. Marx, On the Jewish Question, CW 3: 154, 160-61. 
Rousseauean hostility toward representation per se. ${ }^{61}$ On the contrary, he repeatedly suggests that with the establishment of universal suffrage the promise of popular sovereignty in the political arena was virtually realized. ${ }^{62}$ What distinguishes modern democratic regimes as bourgeois is the fact that popular sovereignty is confined to a public domain beyond which private property rules uncontested in a separate socioeconomic realm. Whereas premodern societies secured class domination by sharply restricting access to the state, modern society secures the rule of the bourgeoisie by removing the economy from political control. Its class power is protected in a private sphere beyond the reach of democratic deliberation and decision-making. ${ }^{63}$ Political emancipation is thus only the prelude to full human emancipation, which requires opening up spaces for political activity throughout bourgeois society. The Marx of 1843 does not renounce work and politics in favor of leisure. On the contrary, he offers the experience of the modern civic community as the alternative to the rule of private property. ${ }^{64}$

To see the capitalists' economic power, concentrated in particular within the workplace, as a form of private rule and the workers as its subjects is the central and distinctive thesis of Marx's Capital. Capitalist private property, writes Marx, "receives its purely economic form by discarding all its former political and social embellishments." ${ }^{15}$ What this means, however, is that capitalism epitomizes the privatization of political power. ${ }^{66}$ The nexus between ownership and sovereignty survived the precapitalist economy. "This power of Asiatic and Egyptian kings, Etruscan theocrats, etc.," Marx writes, "has in modern society been transferred to the capitalist, whether he be an isolated, or as in jointstock companies, a collective capitalist." ${ }^{67}$ Absolute property in

61. See Richard N. Hunt, The Political Ideas of Marx and Engels, 2 vols. (Pittsburgh: University of Pittsburgh Press, 1974, 1984), 1: 81-82.

62. Marx, Contribution to the Critique of Hegel's Philosophy of Law, CW 3: 29-31, 121; Karl Marx, Critique of the Gotha Programme, CW 24: 94-96.

63. Marx, On the Jewish Question, CW 3: 152-53.

64. Ibid., p. 168.

65. Marx, Capital 3: 618.

66. For an excellent discussion of this thesis, see Ellen Meiksins Wood, "The Separation of the Economic and the Political in Capitalism," New Left Review 127 (May-June 1981): 66-95.

67. Marx, Capital 1: 316. 
the means of production invests the capitalist with an unprecedented authority to plan, schedule and organize production. The workplace has its own legal code, internal discipline and modes of punishment. Marx repeatedly refers to the "autocracy of capital" and the "despotism" of the capitalist, a "private legislator ... [with] the law-giving talent of [a] factory Lycurgus. ${ }^{\prime 68}$

The normative standpoint informing this critique recalls Marx's analysis of the Athenian demos. In adopting the political language of classical Greece, Marx points to a contrast between the civic community of the democratic polis and the despotic rule of the capitalist. The capitalist workplace, like the despotic state of antiquity, severs the integral relationship between political freedom and economic masterlessness. Viewed from the democratic polis, the central paradox of the capitalist economy is not so much that it robs people of the leisure its technology makes possible, but rather that it transforms citizens into subjects as they cross the factory's gates. ${ }^{69}$

Marx's analysis of capitalist production occupied his mature years, displacing earlier concerns with the shape of the socialist polity. He returned to these concerns in the 1870s, deeply influenced by the experience of the Paris Commune. The Commune was in his view "the greatest revolution of our century."

Its true secret was this. It was essentially a working class government, the produce of the struggle of the producing against the appropriating class, the political form at last discovered under which to work out the economical emancipation of Labor. ${ }^{70}$

Marx devoted The Civil War in France, and its two drafts and several letters, to unlocking this secret. The enthusiasm evident in these texts is best understood in light of what he learned from his studies of Athenian democracy. ${ }^{71}$ Indeed, one of the most reveal-

68. Marx, Capital 1: 314-15, 400, 410. Elsewhere in the text Marx maintains that "the leadership of industry is an attribute of capital, just as in feudal times the functions of general and judge, were attributes of landed property" (Capital 1: 314-315; see also Capital 3: 382-89). Cf. Booth, Households, pp. 244-46.

69. See Marx, Capital 1: 172. Cf. Booth, Households, p. 233.

70. Karl Marx, The Civil War in France, CW 22: 334.

71. The remarkable similarity between Marx's description of the Commune and the classical polis has not gone unnoticed. See, e.g., Hunt, The Political Ideas of Marx and Engels, 2: 253-56; Gilbert, "Marx's Moral Realism," pp. 158-59, 163-65. In 
ing features of these writings is the reemergence of the language, concepts and themes Marx used to describe full "human emancipation" in the 1840 s. $^{72}$

What drew Marx's attention was not so much the Commune's socioeconomic reforms, which he claimed had "nothing revolutionary in them," as the possibilities inherent in the Commune's democratic measures. ${ }^{73}$ The most revolutionary aspect of the Commune's constitution was its proposal to create a federation of relatively autonomous civic communities throughout the society as a whole. These communities were centers of deliberation on public affairs, where politics involved above all else explicitly raising and challenging claims to rule, and where decisions were the result of argument and deliberation.

In a rough sketch of national organization which the Commune had no time to develop, it states clearly that the Commune was to be the political form of even the smallest country hamlet.... The rural communes of every district were to administer their common affairs by an assembly of delegates in the central town, and these district assemblies

light of his repeated references to the thinness and scarcity of Marx's writings on the anticipated communist society, it is curious that Booth makes no mention of Marx's extensive commentary on the Commune. In fact, this elision is typical of analyses which read Marx from the standpoint of Aristotle's distinction between necessity and freedom. They thus miss the specifically political dimensions of Marx's socialism.

72. Commentaries on the Commune tend to focus on the view, shared by Marx and Engels, that it was a concrete expression of the "dictatorship of the proletariat." Exhaustive studies by Draper and Hunt have shown that this phrase did not have the antidemocratic connotations it acquired in the twentieth century. Both provide extensive documentation of Marx's commitment to democratic political practice. If anything, Marx failed to address the need for safeguards against the excessive spontaneity of popular sovereignty. Proletarian dictatorship, in Marx's view, meant "nothing more and nothing less than 'rule of the proletariat,' the 'conquest of political power' by the working class, the establishment of a workers' state in the first revolutionary period" (Hal Draper, Karl Marx's Theory of Revolution, 4 vols. [New York: Monthly Review Press, 1977-90], 3: 213; see also pp. 269-74). Hunt argues that, for Marx, the Commune's main achievement was the de-professionalization of political life (Hunt, Political Ideas of Marx and Engels, 2: 211-265). What I wish to underscore here is that Marx praised the Commune not so much because it promised proletarian rule or politics without professionals, but rather because it promised to replace the principles of capitalist rule with classical principles of civic association.

73. Marx, The Civil War in France, First Draft, CW 22: 499. 
were again to send deputies to the National Delegation in Paris, each delegate to be at the same time revocable and bound by the mandat impératif (formal instructions) of his constituents. ${ }^{74}$

The emancipatory promise of this regime lay in the uniquely capitalist organization of the realm of necessity. For Marx, the expropriation of capitalists means in the first instance abrogating the political entailments of private property, whereby "the employer combines in his own person the parts of legislator, judge, and executor, and filches the money to boot."75 He offers a model of communism as a system of workers' cooperatives in which republican principles of civic association replace capitalist rule. Work is planned and scheduled by the workers themselves; they organize their own work discipline, choose their own supervisors, hold them accountable, and so on.

If co-operative production is not to remain a sham and a snare; if it is to supersede the Capitalist system; if united co-operative societies are to regulate national production upon a common plan, thus taking it under their own control . . . - what else . . . would it be but Communism, 'possible' Communism? ${ }^{76}$

Politics and political life thus play an architectonic role in Marx's conception of the communist regime. The Marx of The Civil War in France, like the Marx of the 1840s, argues for introducing politics into the historically determined domain of necessity. Democratic rule was to be ensured by the decentralization of political power. Marx refers to the experience of the Commune in the 1872 Preface to the Manifesto by way of criticizing "the revolutionary measures proposed at the end of Section II," which turned precisely on the recommendation "to centralize all instruments of production in the hands of the State."77 One of the crucial lessons of the Commune, he argues, is that

the working class cannot simply lay hold on the ready-made state machinery and wield it for their own purpose. The political instrument

74. Marx, The Civil War in France, CW 22: 332.

75. Ibid., p. 339.

76. Ibid., p. 335.

77. Karl Marx and Frederick Engels, Manifesto of the Communist Party, CW 6: 504. On the evolution of Marx's views toward political centralization and decentralization, see Hunt, Political Ideas of Marx and Engels, 2: 147-161. 
of their enslavement cannot serve as the political instrument of their emancipation. ${ }^{78}$

In Marx's view, capitalism provides a prodigious stimulus to the modern transformation of the public realm into housekeeping written large. The existence of capitalist property exempt from communal responsibilities transfers the direction of public affairs to career civil servants and administrators. The capitalist state takes the form of a vast oikos where "every minor solitary interest engendered by the relations of social groups [is] separated from society itself, fixed and made independent of it and opposed to it in the form of [the] state interest, administered by state priests with exactly determined hierarchical functions. ${ }^{179}$

Leisure from political activity would only exacerbate the problem. Accordingly, Marx recommends politics as a solution to the increasing bureaucratization of modern society. The Commune, he argues, was not only a revolution against the political entailments of private property; it was also "a Revolution against the State itself." 80 In part, this meant that the state's coercive organsmilitary, police, judicature-were transferred from the ruling class into the hands of the working classes. The Communards did not do away with the means of coercion; they ensured by means of universal suffrage that they belonged to everyone. ${ }^{81}$ But for Marx smashing the central state had another, more significant consequence, namely "a resumption by the people for the people, of its own social life." 82

Although the power of the central state is sharply reduced, Marx does not anticipate that the state apparatus will simply

78. Marx, The Civil War in France, Second Draft, CW 22: 533.

79. Marx, The Civil War in France, First Draft, CW 22: 484.

80. Ibid., p. 486.

81. The democratization of the coercive apparatus of the state is Lenin's understanding of the chief accomplishment of the Commune (Vladimir Lenin, The State and Revolution, trans. Henry M. Christman [New York: Bantam Books, 1966], pp. 275, 280-82, 301-303, 338-39). In Lenin's view, politics and the state are exclusively repressive forces. For him, then, communism is tantamount to the withering away of politics and the state (ibid.,pp. 347-49). Rooted more deeply in the classical Greek tradition, Marx discovers in the democratic public realm the institutionalization of freedom.

82. Marx, The Civil War in France, First Draft, CW 22: 486; see also p. 490. 
wither away, at the central or the local level. To be sure, the coercive functions of the state would be curtailed as the need for them, chiefly to defeat armed threats to the new regime, wound down. Nevertheless,

The few but important functions which still would remain for a central government were not to be suppressed, ... but were to be discharged by Communal, and therefore strictly responsible agents ... While the merely repressive organs of the old governmental power were to be amputated, its legitimate functions were to be wrested from an authority usurping pre-eminence over society itself, and restored to the responsible agents of society. ${ }^{83}$

Marx does not specify what these "few but important functions" are, although he does indicate that the state would include agencies for economic planning. ${ }^{84}$ The continued existence of the state, however, means that the use and abuse of political power will still be a problem in the postcapitalist regime. ${ }^{85}$ Hence Marx's concern with ensuring that public officials remain truly responsible agents of their constituents. It is for this reason that he recommends complementing the power of the state with centers of popular sovereignty where citizens would gather not only to provide formal instructions to their representatives in the communal assemblies, but to check political power and prevent its misappropriation. ${ }^{86}$

83. Ibid., pp. 332-33.

84. Marx, The Civil War in France, CW 22: 335. See also Marx, Critique of the Gotha Programme, CW 24: 95. There is a well-known tension in Marx's account of socialism between the desirability of "a common plan" to regulate national production and the desirability of decentralized decision-making by workers' cooperatives. Some kind of market socialism provides an obvious way to reconcile planning with workers' autonomy. But Marx was as hostile to any form of market mechanism as he was to a command economy in which all decisions were made by a central planning agency. It is unclear, then, how socialist economies would allocate scarce factors of production, including labor power, among alternative uses. See Jon Elster, Making Sense of Marx (Cambridge: Cambridge University Press, 1985), pp. 449-56. Moore persuasively argues that this lacuna in Marx's thought is rooted in a pervasive tension between his critique of class and his critique of markets (Stanley Moore, Marx Versus Markets [University Park, PA: The Pennsylvania State University Press, 1993]).

85. See Marx, Critique of the Gotha Programme, CW 24: 94.

86. Marx, The Civil War in France, CW 22: 330-33; see also the First and Second Draft, CW 22: 487-91, 536-38. 
Marx's assessment of the emancipatory potential of the Commune reveals the nature and depth of his debt to classical antiquity. Marx shares the Aristotelian understanding that the economy will always constitute a sphere of necessity, beyond which lies a realm of unconstrained time for the full development of human powers. ${ }^{87}$ The distribution of necessary work was a central issue in the class conflicts he examined, especially in the chapter on the working day (chapter 10) in the first volume of Capital. Capitalism's prodigious productivity makes it possible to greatly reduce the amount of direct labor time historically required to maintain human life, allowing humanity to virtually emancipate itself from Adam's curse.

But there is a deeper understanding of freedom in Marx's text. The reconciliation of freedom and the economy is gained not only by escaping the realm of necessity; it is crucially achieved when human beings abolish class rule, assuming control of their interchange with nature. The claim that Marx offers contradictory definitions of freedom-as, on the one hand, escape from labor and, on the other, escape from masters-rests on a confusion between the transhistorical and the historically determined domains of necessity. ${ }^{88}$ In Marx's view, "disposable time" is not only idle time or leisure; it is also time at one's own disposal, which presupposes in the first instance "that the working masses must themselves appropriate their surplus labor"-that is, that they ... must themselves organize (plan, schedule, direct) their conditions of work. Only "once they have done so" will the sphere of material activities itself be free and compatible with the sphere of leisured activities. ${ }^{89}$

Booth appropriately points out that Marx celebrated the shortening of the working day achieved by the Ten Hours Bill as a victory for the political economy of labor over the political economy of property..$^{90}$ But Marx stressed that "a still greater victory" was achieved by workers' cooperatives in demonstrating that "pro-

87. Marx, Capital 3: 820.

88. See, in particular, Hannah Arendt, The Human Condition (Chicago: The University of Chicago Press, 1958), pp. 104-105; Richard Dien Winfield, Reason and Justice (Albany, NY: State University of New York Press, 1988), pp. 202-203.

89. Marx, Grundrisse, CW 29: 94.

90. Booth, Households, pp. 238-39, 258, 285. 
duction on a large scale, and in accord with the behests of modern science, may be carried on without the existence of a class of masters employing a class of hands." ${ }^{\prime 11}$ The great merit of the cooperative movement "is to practically show, that the ... despotic system of the subordination of labor to capital can be superseded by the republican ... system of the association of free and equal producers. ${ }^{\prime 92}$

\section{Conclusion}

Marx's democratic theory has been enlisted in support of a widely received understanding of politics and its purposes. His conception of a public domain separate from and in some instances opposed to the state recalls Arendt's view of political life. Despite her criticism of Marx, commentators have pointed out "that Marx held a view close to Arendt's ... understanding of the political." ${ }^{\prime 93}$ On this reading, Marx belongs to a tradition, traced back to Aristotle, in which the aim of political activity is selfrealization. The best kind of politics is democratic and agonistic, pursued because it transforms and educates those who participate in it..$^{94}$

Marx's study of the Commune suggests a different conception of democratic politics and its place in postcapitalist society. To be sure, Marx shares the view, common to democratic theory, that politics provides an arena for the development of moral character. The working classes, he writes, "know that in order to work out their own emancipation ... they will have to pass

91. Karl Marx, "Inaugural Address of the Working Men's International Association," CW 20: 11.

92. Karl Marx, "Instructions for the Delegates of the Provisional General Council," CW 20: 190. Although Marx was sharply critical of workers' cooperatives as a strategy for abolishing capitalism, he repeatedly offers them, in both published writings and unpublished manuscripts, as the organizational model of the communist economy (see Capital 3: 387-89, 440; "Notes of Bakunin's Book, Statism and Anarchy, CW 24: 519-20).

93. Schwartz, "Distinction Between Public and Private Life," p. 256. See also Gilbert, "Marx's Moral Realism," pp. 156, 158-59, 162-63, 165.

94. For an excellent critique of this view of political activity, see Jon Elster, "The Market and the Forum," in Foundations of Social Choice Theory, ed. Jon Elster and Aanund Hylland (Cambridge: Cambridge University Press, 1986), pp. 12428. 
through long struggles, through a series of historic processes, transforming circumstances and men." ${ }^{\prime \prime 5}$ The Commune itself "does not [do] away with class struggles, through which the working classes strive to the abolition of classes,... but it affords the rational medium in which that class struggle can run through its different phases in the most rational and human way." 96

The main purpose of political activity, however, is to shape economic decisions. For Marx, the political life of the ordinary producers, ancient and modern, is democratic and instrumental; moral development is a by-product of substantive decision-making. In his analysis of ancient democracy, Finley asks why Athenians jealously guarded "the right of every citizen to speak and make proposals in the Assembly ... yet left its exercise to a few." "One part of the answer," he suggests, "is that the demos recognized the instrumental role of political rights and were more concerned in the end with the substantive decisions, were content with their power to direct those decisions through their power to select, dismiss and punish their political leaders." 97 This account is an apt description of Marx's understanding of political life under communism.

95. Marx, The Civil War in France, CW 22: 335.

96. Marx, The Civil War in France, First Draft, CW 22: 491.

97. Moses I. Finley, Economy and Society in Ancient Greece, ed. Brent Shaw and Richard Saller (New York: Viking, 1981), p. 83. 